\title{
Perceived Usefulness of ICT Usage among JKKK Members in Peninsular Malaysia
}

\author{
Musa Abu Hassan (Corresponding author) \\ Department of Leadership and Management, University of Science and Islamic Malaysia \\ Bandar Baru Nilai, 71800 Nilai, Negeri Sembilan Darul Khusus, Malaysia \\ Tel: 60-3-8947-1870 E-mail:majudesa.desa@gmail.com \\ Bahaman Abu Samah \\ Institute for Social Science Studies, Universiti Putra Malaysia \\ Putra Infoport, 43400 Serdang, Selangor Darul Ehsan, Malaysia \\ Tel: 60-3-8947-1852Ｅ-mail: drbas@ace.upm.edu.my
}

HayrolAzril Mohamed Shaffril

Laboratory of Sustainable Development and Agriculture Extension, Institute for Social Science Studies Universiti Putra Malaysia, Putra Infoport, 43400 Serdang, Selangor Darul Ehsan, Malaysia

Tel: 60-3-8947-1870Ｅ-mail: hayrol82@gmail.com

Jeffrey Lawrence D’Silva

Institute for Social Science Studies, Universiti Putra Malaysia

Putra Infoport, 43400 Serdang, Selangor Darul Ehsan, Malaysia

Tel: 60-3-8947-1862 E-mail: jeffrey@ipsas.upm.edu.my

Received: April 14, 2011

Accepted: June 2, $2011 \quad$ Published: October 1, 2011

doi:10.5539/ass.v7n10p255

URL: http://dx.doi.org/10.5539/ass.v7n10p255

The research is financed by Research University Grant Scheme (Scheme 2) sponsored by Universiti Putra Malaysia.

\begin{abstract}
Information and communication technology (ICT) is indeed an important tool to expose the rural community to development. Realizing the importance of ICT, a number of high impact ICT programs and projects have been introduced by the government. However, do the rural community especially their leaders which are the Village Development and Security Committee members (JKKK) use ICT? And more importantly do they perceive ICT as useful in their daily activities and tasks? This question brings us to the main objective of this paper which is to know the factors that influence the perceived usefulness towards ICT usage among the JKKK members in Peninsular Malaysia. Besides, this paper intends to investigate the level of perceived usefulness towards ICT usage among JKKK members and to reveal the most significant contributors for perceived usefulness towards ICT usage. This is a quantitative study whereby data were gathered using a questionnaire. Based on the multi stage random sampling, a total of $240 \mathrm{JKKK}$ members have been selected as the respondents. Based on the analyses done, it can be concluded that respondents studied do have a high level of perceived usefulness towards ICT usage. All of the four factors studied have a positive and significant relationship towards ICT usage. Attitude was identified as the most significant contributor for perceived usefulness towards ICT usage while the four predictor variables explain about $60.0 \%$ of the variance/variation in perceived usefulness towards ICT usage.
\end{abstract}

Keywords: ICT, Rural community, Village leaders, Perceived usefulness, Attitude 


\section{Introduction}

Musa (2010) has defined ICT as a blend of technology and communication. Technology is a tool or software used to create something. It gives advantages to people in term of saving time and money, effective and secured. On top of it, information technology can be understood as method, tools and software involved in the process of developing, assembling, and processing, managing, distributing and recording uncountable data. ICT is frequently associated with computer and this happens because of its ability to perform all the tasks mentioned above. However, people also admit and realize that the "traditional" ICT tools such as television, radio and newspaper have similar and equal strength and ability as the computer. Since communication media, communication technology and information technology are related to the same thing, thus the concept of Information and Communication Technology has been accepted and used. ICT covers tools; software, content applications and products that have and bring together with it the message, information and knowledge that can be accessed and utilized. It is good to know that a large majority of Malaysian nowadays posses and use ICT and this happens as a result of continuous and persistent government efforts in bringing and exposing ICT to the community.

\subsection{ICT Development in Malaysia}

Information and Communication Technology is playing an important role for the transformation of rural community in Malaysia. Malaysia as one of the developing countries in Asian has benefited from it. Besides of the ICT assisting the government in making the administration process more systematic (Okoronkwo, 2010), the government can use the ICT itself to develop the rural community (Sharifah, 2006 and Kwapong, 2009). ICT doubtlessly is able to help rural community to seek, receive, produce, share, understand and use the information for the purpose of development (Parjo 2001). On top of it, ICT can assist the community to speed up their communication process, save their cost and time. Since the 6th Malaysia Plan, the government has admitted the importance of ICT in building a developed, competitive, knowledgeable and informative community.

ICT is believed to be first developed in Malaysia in the year 1874 through the establishment of the first telephone line. While the computer technology was first introduced in Malaysia in the year 1966 which resulted to the introduction of a number of ICT projects and programs. To further strengthen the development of ICT, the Malaysia government has privatized the telecom sector in 1974 (Musa, 2010). One of the ways to achieve the mission of being a developed country in 2020 is by creating k-community (knowledgeable community). To create k-community, the government has stressed on the development of ICT related infrastructure and potential human capital by involving state, local government as well as the private-public community. On top of it, a total of RM1098 million was allotted for ICT related activities for bridging the digital divide (Kakroo, 2007). Significantly, in the three Malaysia Plans (MP) of the 8th, 9th and 10th, ICT development has been placed as one of the main objectives of the national development. To achieve this, the government has taken policy initiatives and along with the aid of the private partners, a number of ICT projects and programs has been initiated in some remote areas. Interestingly, in these three MP periods a number of high impact ICT projects have been initiated and introduced to the public and among the projects and programs were National Multi Purpose Card, Smart School, Telehealth, e-business, R\&D cluster, Technoprenuer Development, develop the existing cyber cities and expanding the new ones (MSC Phase II) and National Broadband Initiatives (NBI).

To know whether the ICT projects and programs brought by the government has already made an impact to the community, a number of studies have been conducted. Murphy (2008) has revealed that Malaysians spend one hour 25 minutes a day reading print media such as newspaper and magazine, spend one hour 33 minutes a day listening to radio, spend one hour 50 minutes a day watching television, VCD, DVD and other video sources. Murphy has also emphasized that the usage of internet among Malaysians is at a good level where on average Malaysians allocate two hours and 47 minutes on internet usage a day. Interestingly, Musa (2008) have identified that Malaysian have already used the ICT for the purpose of expanding their business while Shaffril et al. (2010) and Musa (2008) have emphasized that Malaysian especially those in the rural areas have started to use the ICT for their personnel and daily tasks, and for performing their jobs. Malaysian Communication and Multimedia Commission (2008) has concluded that a total of $15.7 \%$ of Malaysian use the internet for more than 28 hours a week, majority of Malaysian used the internet for the purpose of seeking knowledge and information and a total of $24.8 \%$ of internet users in Malaysia are those whose age are more than 40 years old. These information can be seen as an indicator that all the ICT projects, programs, initiatives and agendas have brought about positive impacts.

\subsection{VDSC in Malaysia}

The establishment of Village Development and Security Committee or locally called Jawatankuasa Kemajuan 
dan Keselamatan Kampung (JKKK) was established in 1962, 5 years after Malaysia gained its independence. JKKK was formally established in accordance to Order No 3, Plan on Country and Rural Development 1962. JKKK was given the responsibility to lead the village community and as the representative of the government within their administered areas. JKKK can be the channel for the government to be close to the rural community. Through the JKKK, the government will be informed on the rural communities' needs, problems and development. At that time, JKKK has been used by the government as a tool to intensify and strengthen the socio-economic aspects of the rural community such as income, education and others.

\subsection{Rural Development through ICT in Malaysia}

The government supports are indeed important keys to encourage the community to use ICT (Olajubu et al., 2006 and Alfantookh et al., 2008). Malaysia government has persistently come out with a number of ICT projects for the rural community. The two most successful ICT projects that were specifically designed for the rural community are the Rural Internet Center, locally known as PID and Rural Info Center, locally known as MID. PID projects were started back in 2000 by the Ministry of Information Communication and Culture (MICC). In 2011, the 11th year of the PID establishment, there are 40 PID nationwide, a significant increase of 26 PID centers compared to only 14 PID centers in its earlier year of establishment in 2000 . All of the states in Malaysia have its own PID with Selangor and Johor securing the highest number of PID. Interestingly, all PIDs are located at the post office based on the reasons that the post office is one of the centers of attraction of the community and it provides a lot of facilities to the public. PID was given the responsibility of filling the gap that exists between the rural and urban community in term of ICT usage, skills and knowledge. Besides, PID also offers persistent ICT trainings and encourages local content development. Among the trainings included are computer applications, e-mail usage and website surfing (Narimah et al, 2010).

A year after the establishment of PID, the MID was set-up by the Ministry of Rural and Regional Development (MRRD) through their Infodesa Program. Almost similar to the PID objective, the main objective of MID is to expose the rural community to the ICT facilities and conduct basic ICT trainings. Among the services offered in MID are training on basic and advance computer skills, computer and internet services, Infodesa portal, printing, website services, computer repair and information on villages nationwide. (Narimah et al., 2010). The government has never stopped its efforts in bringing the positive impact of the ICT to the rural community and this can be proved with the establishment of National Broadband Initiatives (NBI). NBI was initiated to encourage the community to possess and use the broadband services.

\subsection{Factors studied}

\subsubsection{Perceived Usefulness and Perceived Ease of Use}

Perceived usefulness towards ICT usage can occur when a person believes that utilizing a certain technology will assist him to increase or double his or her job performance. People will prefer to utilize an application if it will aid them to intensify their task performance (Davis 1989). For JKKK members ICT can be considered as useful when it helps the JKKK members in performing their daily and administration tasks such as writing letters, doing budgeting, power point presentation and reading newspaper.

Meso et al. (2005) have emphasized that perceived usefulness and perceive ease of use, greater reliability of the technology and easier access to ICT are among the important catalyst for better confidence thus create a better usage of ICT. When community perceived that ICT is useful, it will create a sustainable usage of ICT. Perceived usefulness must be persistent to have a better impact on ICT usage (Rogers, 2003). ICT can be perceived useful if it involves low cost, has the ability to reach wider market and able to gather large information within a short time (Laudon and Laudon, 2000 and Ongori, 2009).

Furthermore, the available literatures related to ICT usage provide evidence on the influence of perceived usefulness on intention to use ICT (Argawal and Prasad, 1999; Hu et al. 2003 and Venkatesh and Morris, 2000). Besides, there are also extensive research that proved whether or not perceived ease of use has influence on ICT usage (Venkatesh and Davis, 1996).

\subsubsection{Attitude}

Attitude reflects someone's like or dislike towards something (Luarn and Lin, 2005). Positive attitude is an important component for someone to use ICT (Onasanya et al., 2010 and Shiro (2008) has stressed that rural community like ICT and they need ICT projects at their areas. Nevertheless, Shiro (2008) revealed that even though they have this kind of positive attitude towards ICT, lack of ICT knowledge and skills have obstruct them from use ICT frequently.

Continuous usage and exposure to ICT must be emphasized if the positive attitude towards ICT usage is to be 
cultivated among the rural community (Zhang, 2009). Moreover, according to Dixon (2009), having a persistent usage and exposure to ICT will create an expert on ICT. Yi, et al. (2005) believed that individual differences can be an important factor to form a positive attitude towards ICT usage; people with different age, gender and locality will have different attitude and perception towards ICT usage. Rural community usually is related with negative attitude towards ICT usage compared to their counterpart in the urban areas.

On the other hand, Duan et al. (2009), knowledge and experience have influence on attitude towards ICT. Lack of knowledge on ICT will keep people in rural areas away from the ICT services such as internet and telecommunication and this directly will create people's negative attitude towards ICT. Furthermore, computer anxiety is identified as one of the reasons for people's resistance to use ICT (Russel and Bradley, 1997).

\subsubsection{Self-efficacy}

An individual's belief in his or her ability to successfully do a specific behavior can be called as self-efficacy. There are a number of existing literatures that have revealed the influence of self-efficacy on one's ICT usage (Olfman and Mandviwalla, 1994; Compeau, et al., 1999 and Johnson and Marakas, 2000). Besides, self-efficacy also is seen as one of the factors that was found as one of the dominant contributors towards ICT usage (Venkatesh and Davis, 2000;Venkatesh et al., 2003 and Lewis et al., 2003). However, there are also some studies that disagreed with what have been found by studies mentioned above when they found insignificant relationship between self-efficacy and ICT usage (Bolt et al., 2001 and Gallivan et al., 2005).

\subsubsection{Subjective Norm}

Venkatesh and Davis (2000) stressed that subjective norm is the technology user's belief that he/she should or not perform the behavior to accept the technology. There are a lot of previous studies that have revealed the subjective norms impacts on the ICT usage among the rural community (Gilligan, 2005 and Zulkifli and Sulaiman, 2009 and Pee and Kankanhalli, 2010). Gilligan (2005) through his study has revealed the influence of subjective norm on ICT usage by concluding that community in the rural areas use computer less because they are surrounded by the people who use the computer less and there are also lack of ICT infrastructures which can cause them to have less interest to use ICT.

Based on the literatures mentioned above, it is obvious that perceived usefulness is one of the important factors for ICT usage. The same case also occur with the four other factors namely perceived ease of use, attitude, self-efficacy and subjective norm. All of these four factors seem to have a significant influence on ICT usage. However, do these four factors have any relationship with perceived usefulness towards ICT usage? This is the main question of the study and will be answered in the next part of this paper.

\section{Methodology}

To meet the objective of this study, a total of 240 respondents were selected. The respondents were chosen based on the multi stage random sampling. The total population of this study is $69,810 \mathrm{JKKK}$ members. To determine the appropriate number for the required analyses, the G-Power analysis was employed. The selected respondents were among the JKKK members from 24 selected villages in Peninsular Malaysia. Four states have been chosen to be involved in this study namely Terengganu (represented east coast zone), Perak (represented central zone), Kedah (represented northern zone) and Johor (represented southern zone). Survey was conducted with the selected respondents and for each of the questions asked, the respondents were given a choice of 10 Likert-like scale. The dependent variable for this study is perceived usefulness towards ICT usage and there are four independent variables in this study namely perceive ease of use, attitude, self-efficacy, and subjective norm.

In order to fulfill the objective determine, descriptive and inferential analyses were employed. To describe the general data of the study descriptive analyses such as frequency, percentage mean and median were employed. For identifying any factors that might have any relationship with perceived usefulness towards ICT usage among JKKK members, Pearson product-moment correlation was employed while for identifying any factors that might contribute towards perceived usefulness towards ICT usage among JKKK members, a multiple linear regression (Stepwise method) has been used

\section{Results}

\subsection{Respondents' Background}

The results on the respondents background focused on nine questions pertaining to age, level of education, type of job, income per month, experience of holding a position in JKKK, position in VDSC, whether or not they have attended any ICT course, duration of computer usage a week and duration of internet usage in a week. The results gained are presented in Table 1. 
The mean age of respondents was 50.0 years with majority of the respondents $(34.2 \%)$ were in the age group of 41-50 years old. Comparatively, more than half of the respondents (52.5\%) possess SPM/SPMV level of education, $27.1 \%$ possess PMR level of education and 20.4\% possess pre-university and university level of education. Moreover, majority of the JKKK members are among those who are self-employed (35.5\%). The mean score recorded for income per month was RM 1,507.90 where majority of the respondents were found to earn $>$ RM1, 501 a month compared to those who earn $<$ RM750 a month (29.1\%). It can be seen that most of the respondents interviewed were among those who are new in the JKKK organization when more than two fifth of them $(42.1 \%)$ were found to hold the JKKK position for less than 5 years. Not too many of the respondents $(30 \%)$ have gone to any ICT course. It is a positive sign when it was revealed that majority of the respondents used computer between 1-9 hours a week (45.4\%) and used the internet for more than 8 hours a week $(28.8 \%)$ (Table $1)$.

\subsection{Overall Level of Perceived Usefulness towards ICT Usage}

It is a positive indicator that the respondents studied have a high level of perceived usefulness towards ICT usage, based on the overall level of mean recorded which is 6.88 . Majority of the respondents $(67.1 \%)$ were found to have a high level of perceived usefulness towards ICT usage while minority of the respondents $(12.1 \%)$ was found to have a low level of perceive usefulness towards ICT usage. A total of $20.8 \%$ of the respondents were found to have a moderate level of perceived usefulness of ICT usage (Table 2).

\subsection{Perceived Usefulness towards ICT Usage}

A total of nine statements to measure perceived usefulness towards ICT usage have been included in the questionnaire. Based on the data gained (Table 3), majority of the respondents seems to agree that ICT is useful for saving the data in a large scale and this can be proven when the statement of "Saving data in a large capacity" recorded the highest mean score $(\mathrm{M}=7.10)$. Besides believe that ICT is useful for saving the data in a large scale, the eight other statements have been identified to manage to record mean score more than 6.00 . The statements are 1) "Increase work quality" $(\mathrm{M}=7.08), 2)$ "Enhance ICT knowledge and information" $(\mathrm{M}=6.99)$, 3) "Enhance ICT skills" ( $(M=6.99)$, 4) "Enhance work productivity" $(M=6.98)$, 5) "Speed up the communication process" $(\mathrm{M}=6.95), 6)$ "Ease the financial budget tasks" $(\mathrm{M}=6.67), 7)$ "Save spaces" $(\mathrm{M}=$ $6.65)$ and 8$)$ "Save money" ( $\mathrm{M}=6.48)$.

To gain the overall level of the four independent variables studied, a cumulative mean score was obtained. The cumulative mean score then was grouped into three groups namely low, moderate and high for the mean score of 1 to $3.33,3.34$ to 6.67 and 6.68 to 10.0 respectively. Table 4 shows the level of four independent variables studied namely perceived ease of use, attitude, self-efficacy and subjective norm. All of the four independent variables recorded a moderate mean score (based on the mean score from 4.82 to 6.50). Perceived ease of use recorded the highest mean score $(\mathrm{M}=6.50)$ followed by attitude $(\mathrm{M}=5.91)$. Comparatively, the lowest mean score was recorded by subjective norm $(\mathrm{M}=5.32)$.

\subsection{Factors Explaining the Variation of perceived usefulness towards ICT usage}

A four factor linear regression model was projected to clarify the variation of perceived usefulness towards ICT usage among JKKK members and the factors were attitude (X1), self-efficacy(X2), perceived ease of use (X3) and subjective norm (X4). Thus, the equation of the projected multiple linear regression model is as follows:

$$
\mathrm{Y}(\text { Perceived usefulness towards ICT usage })=\mathrm{b} 0+\mathrm{b} 1(\mathrm{X} 1)+\mathrm{b} 2(\mathrm{X} 2)+\mathrm{b} 3(\mathrm{X} 3)+\mathrm{b} 4(\mathrm{X} 4)+\mathrm{e}
$$

Where:

$\mathrm{Y}=$ Perceived usefulness towards ICT usage

b0 $=$ Constant (Intercept)

b1-5= Estimates (Regression coefficients)

$\mathrm{X} 1=$ Attitude

$\mathrm{X} 2$ = Self-efficacy

$\mathrm{X} 3$ = Perceived ease of use

$\mathrm{X} 4$ = Subjective norm; and

$\mathrm{e}=$ Error

To examine to what extent the research data fit the projected multiple linear regression model, enter regression method was used. All of the four predictor variables were significant in explaining perceived usefulness towards 
ICT usage $\mathrm{F}(4,240)=88.73, \mathrm{p}=.0001$. The four predictor variables were: attitude $(\mathrm{t}=4.82, \mathrm{p}=.000)$, self-efficacy $(t=2.50, p=.013)$, perceived ease of use $(t=3.47, p=.001)$ and subjective norm $(t=2.157, p$ $=.032$ ) This suggests that four-predictor MLR model was fully supported by the research data.

As depicted in the coefficients table (see Table 5), the estimates (B weights) of the model coefficients for b0 are $1.81, \mathrm{~b} 1$ is $0.34(\mathrm{X} 1), \mathrm{b} 2$ is $0.16, \mathrm{~b} 3$ is 0.23 and $\mathrm{b} 4$ was 0.13 According to this $\mathrm{B}$ weights, the estimated regression equation model as follows:

$\mathrm{Y}($ Perceived usefulness towards ICT usage $)=1.81+0.34(\mathrm{X} 1)+0.16(\mathrm{X} 2)+0.23(\mathrm{X} 3)+0.13(\mathrm{X} 4)+\mathrm{e}(2)$

Where:

$\mathrm{Y}=$ Perceived usefulness towards ICT usage

$\mathrm{b} 0=$ Constant (Intercept)

b1-5= Estimates (Regression coefficients)

$\mathrm{X} 1=$ Attitude

$\mathrm{X} 2$ = Self-efficacy

$\mathrm{X} 3$ = Perceived ease of use

$\mathrm{X} 4$ = Subjective norm; and

$\mathrm{e}=$ Error

The R-squared of 0.60 implies that the four predictor variables explain about $60.0 \%$ of the variance/variation in perceived usefulness towards ICT usage. The ANOVA table tests the null hypothesis and the multiple $\mathrm{R}$ in the population equals 0 . The ANOVA table revealed that the F-statistics $(F(4,240)=88.73)$ is very large and the corresponding p-value is highly significant $(0.0001)$ or lower than the alpha value of 0.05 indicating that the null hypothesis was rejected and thus the multiple $\mathrm{R}$ is not equal to zero, and thus confirming that there is linear relationship between four predictor variables and perceived usefulness towards ICT usage.

The largest beta coefficient is 0.34 which is for attitude and make this variable as the strongest unique contribution in explaining the dependent variable (perceived usefulness towards ICT usage), when the variance explained by all other predictor variables in the model is controlled for. It suggests that one standard deviation increase in attitude is followed by 0.342 standard deviation increase in perceived usefulness towards ICT usage. The Beta value for self-efficacy is 0.19 , perceived ease of use was 0.23 , while standardize coefficient for subjective norm was the smallest (.12) and indicating that it made the least contribution (Table 5).

A number of ways can be used to examine the existence of multicollinearity of the MLR model. The first one is using the correlation table (see Table 6) recommended that the correlation between each of the independent variable was highly correlated with the other independent variables.

\section{Discussion}

As the result of this study has shown, JKKK members studied have a high level of perceived usefulness towards ICT usage. Majority of the JKKK members studied perceived ICT is useful to them in term of saving a large capacity of data, increase work quality, enhance ICT knowledge and information, enhance ICT skills, enhance work productivity, speed up communication process, ease the financial budget tasks, save time and save money. All of these findings have proved that the findings of Davis (1989) are consistent with the findings of this study. Davis (1989) has stressed that people will prefer to utilize an application if it will help them to perform better in their job.

All of the assistance provided by the ICT without doubt will help a lot in term of JKKK members' administration works. When all of these kinds of assistance are available for the JKKK members, it can contribute towards more efficient and effective works among JKKK members. This is not surprising as it is consistent with what have been found by Meso et al. (2005) who have emphasized that perceived usefulness and perceive ease of use, greater reliability of the technology and easier access to ICT are among the important catalyst for better confidence thus create a better usage of ICT. Furthermore, future research should be conducted in order to investigate other factors that influence on perceived usefulness towards ICT usage.

To further enhance perceived usefulness towards ICT usage among JKKK members, this study has recommended that ICT usage within the JKKK organization should be more widespread and the JKKK members should be supported both technically and educationally and the process should be planned and included in the strategies and policies of the related and responsible agencies and this is not new as the same recommendation 
was also emphasized by Usluel et al., 2008. On top of it, actions and plans to construct a positive attitude towards ICT should be started. As been proven by this study, attitude was the most contributors for perceived usefulness towards ICT usage and one of the best ways to construct positive attitude towards ICT usage is the JKKK members should be provided with all suitable ICT facilities which can assist them in their administration works. Findings revealed by Butler and Sellbom (2002) are consistent with the findings of this study by stating that ICT facilities have a strong impact on perceived usefulness towards ICT usage. However, Usluel et al. (2008) have stressed that it is useless to have all the facilities if the targeted group do not have at least a basic ICT knowledge and skills. Therefore, responsible and related agencies can play their role in educating and providing more ICT knowledge and skills for the JKKK members. The education process should also be persistent and continuous as Ndag et al., (2008); Rogers (2003)and Carey et al (2002), revealed that one of the crucial factors which enable to enhance the perceived usefulness towards ICT usage is ICT education and trainings. According to Carey et al (2002), the frequency of attending ICT courses and seminars has something to do with the perceived usefulness towards ICT usage. Besides, by having the training skills, it will educate the JKKK members on how the roles of ICT can play to assist them in their works and more importantly to their village development.

\section{Conclusion}

Data gained have shown that majority of the respondents studied were age between 41-50 years old, possess SPM/SPMV level of education, self-employed, earn between RM1,501 or more a month, have held a position in JKKK for 5 years or less, never attended ICT course use computer for 1-9 hours a week and use the internet for 8 hours or more a week. It is interesting to reveal that majority of the JKKK members in Malaysia have a high level of perceived usefulness towards ICT usage. The survey revealed their level of perceived ease of use, attitude, subjective norm, and self-efficacy were moderate. In addition, attitude, perceived ease of use, subjective norm and self-efficacy are important factors in explaining variation of perceived usefulness towards ICT usage. Thus the four-factor model was fully supported by the research data. The expected positive linear relationship for $\mathrm{X} 1$ (attitude) and Y, X2 (self-efficacy) and Y, X3 (perceived ease of use) and Y and X4 (subjective norm) and Y. Overall, the model is a very good descriptor of the variation of perceived usefulness towards ICT usage and it was found to be stable and reliable model.

\section{References}

Alfantookh, A.A. Al-Hazmi, K.M. \& Bakri, A.H. (2008). Assessment Indicators for Information Technology in Higher Education Institutions: A STOPE approach. Asian Information Management. 2(1), 1-13. http://dx.doi.org/10.3923/ajim.2008.1.13

Argawal, R. \& Prasad, J. (1999). Are Individual Difference Germane to the Acceptance of New Information Technologies? Decision Science, 30(2), 361-391. http://dx.doi.org/10.1111/j.1540-5915.1999.tb01614.x

Bolt, M.A. Killough, L.N. \& Koh, H.C. (2001). Testing the Interaction Effects of Task Complexity in Computer Training Using the Social Cognitive Model. Decision Science, 32(1), 1-20. http://dx.doi.org/10.1111/j.1540-5915.2001.tb00951.x

Butler, D.L. \& Selbom, M. (2002). Barriers to adopting technology for teaching and learning. Educause Quarterly, 2: 22-28. [Online] Available: http://net.educause.edu/ir/library/pdf/EQM0223.pdf

Carey, J. Chisholm, \& I. Irwin, L. (2002). The Impact of Access on Perception and Attitudes towards Computers: an International Study. Educational Media International, $39 \quad(3 \& 4), \quad 223-235$. http://dx.doi.org/10.1080/09523980210166431

Compeau, D. Higgins, C.A. \& Huff, S. (1999). Social Cognitive Theory and Individual Reaction to Computing Technology: A Longitudinal Study. MIS Quarterly. 23(2), 145-158. [Online] Available: http://www.jstor.org/stable/249749

Davis, F.D. (1989). Perceived usefulness, Perceive Ease of Use and User Acceptance of Information Technology. MIS Quarterly, 13(3), 319-340. [Online] Available: http://www.jstor.org/stable/249008

Duan, M. Warren, M. Lang, Y. Lu, S. \& Yang, L. (2009). An Analysis of ICT Development Strategy Framework in Chinese Rural Areas. Computer and Computing Technologies in Agriculture, 3, 1835-1844. http://dx.doi.org/10.1007/978-1-4419-0213-9_33

Fishbein, M, \& Ajzen I. (1975). Belief, attitude, intention and behavior: An introduction to theory and research. Reading, MA, Don Mills, Ontario: Addison-Wesley Publication Company.

Gallivan, M.J. Spitler V.K. \& Koufaris, M. (2005). Does Information Technology Training Really Matter? A 
Social Information Processing Analysis of Coworkers' Influence on IT Usage in The Work Place. Management Information Systems, 22(1), 153-192. [Online] Available: http://www.jstor.org/stable/40398761

Gilligan, R. (2005). Questioning the "Rural" Adoption and Use of ICTs. Computer Science, 32(5), 155-167. http://dx.doi.org/10.1007/1-4020-3872-0_10

Hu, P.J., Clark, T.H.K \& Ma, W.W. (2003). Examining Technology Acceptance By School Teachers: A $\begin{array}{llll}\text { Longitudinal Study. Information and } & \text { Management, } & \text { 41(2), }\end{array}$ http://dx.doi.org/10.1016/S0378-7206(03)00050-8

Johnson, R.D. \& Marakas, G.M. (2000). Research Report: The Role of Behavioral Modeling in Computer Skills Acquisition: Towards Refinement of the Model. Information System Research, 11(4), 402-417. http://dx.doi.org/10.1287/isre.11.4.402.11869

Kakroo, U. (2007). ICT empowering citizens of Malaysia: development with destiny. [Online] Available: http://unpan1.un.org/intradoc/groups/public/documents/APCITY/UNPAN026242.pdf

Kwapong, O.A.T.F. (2009). Comparing Knowledge and Usage of ICT among Male and Female Distance Learners of an Endowed and Deprived Area in A Developing Country in Africa. Information Technology Education, 8, 1-17. [Online] Available: http://jite.org/documents/Vol8/JITEv8p001-017Kwapong415.pdf

Laudon, K.C. \& Laudon, J.P. (2000). Management information systems: organization and technology in the networked enterprise, 6th ed. Prentice-Hall, Englewood Cliffs, NJ.

Lewis, W., Argawal R. \& Sambamurthy, V. (2003). Sources of Influence on Belief about Information Technology Use: An Empirical Study of Knowledge Workers. MIS Quarterly, 27(4), 657-678. [Online] Available: http://www.jstor.org/stable/30036552

Luarn, P, Lin, H. (2005). Towards An Understanding of the Behavioral Intention to Use Mobile Banking. Computer in Human Behavior. 21, 873 -891. http://dx.doi.org/10.1016/j.chb.2004.03.003

Malaysian Communication and Multimedia Commissions, (2008). Q4, 2008, Communication and multimedia, selected facts and figures. [Online] Available: http://www.skmm.gov.my/link_file/facts_figures/stats/pdf/SKMM_Q4.pdf

Meso, P., Musa, P. \& Mbarika, V. (2005). Towards A Model of Consumer Use of Mobile Information and Communication Technology in LDCs: The case of Sub-Saharan African. Information Systems, 15(2005), 119-146. http://dx.doi.org/10.1111/j.1365-2575.2005.00190.x

Murphy, S. (2008). Insights into critical trends that are shaping the lives of Malaysian consumers. [Online] Available: http://www.adoimagazine.com/newhome/images/_docs $/ 5 \% 20$ hot $\% 20$ trends $\% 20$ for $\% 20$ Malaysia.pdf

Musa, A.H. (2008). Benefiting ICT for all. Serdang: UPM Publisher.

Musa, A.H. (2010). Information and Communication Technology and community development. Paper presented at IPSAS Intellectual Discourse, IPSAS Meeting Room, University Putra Malaysia, Serdang, Selangor, 22 October 2010.

Narimah, I. Musa, A.H. Jusang, B. SitiZobidah, O. Yadi, S Zamre Y. \& Nurani, K. (2010). Profiling of rural ICT projects. In Media and Agriculture Extension (pp. 48-66). A.S Bahaman., U. Jegak and A. Khatijah, (Eds.).UPM Publisher.

Ndag, I., Sanusi, R.A. \& Aigbekaen, E.O. (2008). Comparative analysis of Information and Communication Technology (ICT) used by agricultural extension workers in South-west and North-central Nigeria. Paper presented at the 19th Annual International Management Association, 13-15 October 2008, San Diego, California, USA.

Okoronkwo, M.C. (2010). A Model for E-Governance System Implementation for Developing Countries. Asian Information Management. 1, 1-11. http://dx.doi.org/10.3923/ajim.2010.1.11

Olajubu, E.A. Oyawelu, I.O. Kumalolo, F.O. \& Ninan, D.F. (2006). A Framework for Penetration of Information Communication Technology into Developing Countries for Manpower and Economic Development. Information Technology Journal, 5(1), 30-34. http://dx.doi.org/10.3923/itj.2006.30.34

Olfman, L. \& Mandviwalla, M. (1994). Conceptual Versus Procedural Software Training for Graphical User Interfaces: A Longitudinal Field Experiment. MIS Quarterly, 18(4), 405-426. [Online] Available: http://www.jstor.org/stable/249522

Onasanya, S.A., Shehu, R.A. Oduwaiye R.A. \& Shehu, L.A. (2010). Higher Institution Lecturers' Attitude 
towards Integration of ICT into Teaching and Research in Nigeria. Research Information Technology, 2, 1-10. http://dx.doi.org/10.3923/rjit.2010.1.10

Ongori, H. (2009). Roles of Information and Communication Technologies Option in SMES: Evidence from Botswana. Research Information Technology, 1(2), 79-85. http://dx.doi.org/10.3923/rjit.2009.79.85

Parjo. (2001). Zone the road to finish information society: a statistical experience. Paper presented at INFOSOC 2001, 14-15 Jun 2001. Hotel Equatorial Pulau Pinang.

Pee, L.G. \& Kankanhalli, A. (2010). Bridging the Digital Divide: Use Of Public Internet Kiosk in Mauritius. Global Information Management, 18(1), 15-38. http://dx.doi.org/10.4018/jgim.2010091102

Rogers, E.M. (2003). Diffusion of Innovations, 5th ed. The Free Press, New York, NY.

Russel, G. \& Bradley, G. (1997). Teacher Computer Anxiety: Implication for Professional Development. Education Information Technology, 2, 17-30. http://dx.doi.org/10.1023/A:1018680322904

Shaffril, H.A.M., B.A. Samah, M.A. Hassan \& J.L. D'Silva. (2010). Socio-economic Factors That Impinge Computer Usage in Administration Works among Village Leaders in Malaysia. Scientific Research and Essays. 5, 3623-3633. [Online] http://www.academicjournals.org/sre/PDF/pdf2010/4Dec/Shaffril\%20et\%20al.pdf

Available:

Sharifah, S.S.N. (2006). ICT centers for rural community in Peninsular Malaysia. Inaugural Lecture Series. Technology University of Malaysia Publisher, Skudai Johor.

Shiro, U. (2008). A Case Study of DIY ICT. Journal of Information, 10(4), 46-60. http://dx.doi.org/10.1108/14636690810887535

Usluel, Y.K., Askar, P. \& Bas, T. (2008). A Structural Equation Model for ICT Usage in Higher Education. Educational Technology and Society, 11(2), 262-273. [Online] Available: http://www.ifets.info/journals/11_2/19.pdf

Venkatesh, V, \& Morris, M.G. (2000). Why Not Men Ever Stop To Ask for Directions? Gender, Social Influence and Their Role in Technology Acceptance and Usage Behavior. MIS Quarterly, 24(1), 115-139. [Online] Available: http://www.jstor.org/stable/3250981

Venkatesh, V. \& Davis, F.D. (1996). A Theoretical Extension Of Technology Acceptance Model: Four Longitudinal Field Studies. $\quad$ Management Science, $46(2), \quad$ 186-204. http://dx.doi.org/10.1287/mnsc.46.2.186.11926

Venkatesh, V., Morris, M.G. Davis G.B. \& Davis, F.D. (2003). User Acceptance of Information Technology: toward a Unified View. MIS Quarterly, 27 (3), 425-478. [Online] Available: http://www.jstor.org/stable/30036540

Yi, Y., Wu Z. \& Tung, L.L. (2005). How Individual Differences Influence Technology Usage Behavior: Toward An Integrated Framework. Computer Information Systems, 46, 52 -63.

Zhang, P. \& Aikman, S. (2007). Attitudes in ICT Acceptance and Use. Human-Computer Interaction, (2007), 1021-1030. http://dx.doi.org/10.1007/978-3-540-73105-4_112

Zulkifli, I. \& Sulaiman, A. (2009). The Influence of Malaysian Telecenters on Community Building. Electronic e-Government, 7, 77-86. [Online] Available: http://www.ejeg.com/volume7/issue1 
Table 1. Socio-economic Data of the Respondents

$\begin{array}{lllll}\text { Variables } & \text { Frequency } & \text { Percentage } & \text { Mean } & \begin{array}{l}\text { Standard } \\ \text { deviation }\end{array}\end{array}$

\begin{tabular}{|c|c|c|c|c|}
\hline \multicolumn{5}{|l|}{ Age } \\
\hline$\leq 40$ years & 51 & 21.2 & 50.0 & 11.0 \\
\hline 41-50 years & 82 & 34.2 & & \\
\hline $51-60$ years & 60 & 25.0 & & \\
\hline$\geq 61$ years & 47 & 19.6 & & \\
\hline \multicolumn{5}{|l|}{ Level of education } \\
\hline PMR * and primary school & 65 & 27.1 & & \\
\hline SPM/SPMV** & 126 & 52.5 & & \\
\hline University and Pre University & 69 & 20.4 & & \\
\hline \multicolumn{5}{|l|}{ Type of job } \\
\hline Self-employed & 85 & 35.5 & & \\
\hline Retiree/housewives & 62 & 25.8 & & \\
\hline Government & 56 & 23.3 & & \\
\hline Private & 37 & 15.4 & & \\
\hline Income per month & & & 1507.90 & 990.56 \\
\hline$<$ RM750 & 70 & 29.1 & & \\
\hline RM751-RM1500 & 81 & 33.8 & & \\
\hline$>\mathrm{RM} 1501$ & 89 & 37.1 & & \\
\hline \multicolumn{5}{|l|}{$\begin{array}{l}\text { Value in Ringgit Malaysia } \\
\text { (RM) }\end{array}$} \\
\hline \multicolumn{5}{|l|}{$\begin{array}{l}\text { Experience of holding a } \\
\text { position in VDSC }\end{array}$} \\
\hline$\leq 5$ years & 101 & 42.1 & 8.44 & 1.80 \\
\hline $6-10$ years & 85 & 35.4 & & \\
\hline$\geq 11$ years & 54 & 22.5 & & \\
\hline \multicolumn{5}{|l|}{ Have attended any ICT course } \\
\hline Yes & 72 & 30.0 & & \\
\hline No & 168 & 70.0 & & \\
\hline $\begin{array}{l}\text { Period of computer usage a } \\
\text { week }\end{array}$ & & & 11.07 & 9.67 \\
\hline 0 hours & 31 & 12.9 & & \\
\hline 1-9 hours & 109 & 45.4 & & \\
\hline$\geq 10$ hours & 100 & 41.7 & & \\
\hline $\begin{array}{l}\text { Period of internet usage a } \\
\text { week }\end{array}$ & & & 9.05 & 8.68 \\
\hline 0 hours & 62 & 25.8 & & \\
\hline 1-3 hours & 48 & 20.0 & & \\
\hline 4-7 hours & 61 & 25.4 & & \\
\hline$\geq 8$ hours & 69 & 28.8 & & \\
\hline
\end{tabular}

*PMR $=$ Malaysia Lower Education Certificate

**SPM/SPMV= Malaysia Education Certificate/Malaysia Vocational Education Certificate 
Table 2. Overall Level of Perceived Usefulness towards ICT Usage

\begin{tabular}{lllll}
\hline Level & Frequency & Percentage & Mean & SD \\
\hline & & & & \\
Low (1-3.33) & 29 & 12.1 & $\mathbf{6 . 8 8}$ & $\mathbf{2 . 4 3}$ \\
Moderate (3.34-6.67) & 50 & 20.8 & & \\
High (6.68-10.0) & 161 & 67.1 & & \\
\hline
\end{tabular}

Table 3. Statements of Perceived Usefulness towards ICT Usage

\begin{tabular}{|c|c|c|c|c|c|c|c|c|c|c|c|c|}
\hline \multirow[t]{2}{*}{ Statements } & \multicolumn{10}{|c|}{ Scale } & \multirow[t]{2}{*}{ Mean } & \multirow[t]{2}{*}{ SD } \\
\hline & 1 & 2 & 3 & 4 & 5 & 6 & 7 & 8 & 9 & 10 & & \\
\hline $\begin{array}{l}\text { Saving data in a large } \\
\text { capacity }\end{array}$ & 7.9 & 4.2 & 2.5 & 2.1 & 6.7 & 7.9 & 9.6 & 19.6 & 22.5 & 17.1 & 7.10 & 2.73 \\
\hline Increase work quality & 5.0 & 4.2 & 3.3 & 3.3 & 7.1 & 7.5 & 12.5 & 24.2 & 28.8 & 14.2 & 7.08 & 2.51 \\
\hline $\begin{array}{l}\text { Enhance ICT } \\
\text { knowledge and } \\
\text { information }\end{array}$ & 5.0 & 5.0 & 2.9 & 3.3 & 8.3 & 7.9 & 12.1 & 25.4 & 15.0 & 15.0 & 6.99 & 2.54 \\
\hline Enhance ICT skills & 5.0 & 5.0 & 2.5 & 4.2 & 7.1 & 7.9 & 14.3 & 23.8 & 16.2 & 14.2 & 6.99 & 2.53 \\
\hline $\begin{array}{l}\text { Enhance work } \\
\text { productivity }\end{array}$ & 6.2 & 5.4 & 1.7 & 1.7 & 7.5 & 10.0 & 13.3 & 21.7 & 20.4 & 12.1 & 6.98 & 2.56 \\
\hline $\begin{array}{l}\text { Speed up the } \\
\text { communication process }\end{array}$ & 7.5 & 5.0 & 1.7 & 4.6 & 7.1 & 7.1 & 11.2 & 21.2 & 18.8 & 15.8 & 6.95 & 2.72 \\
\hline $\begin{array}{l}\text { Ease the financial } \\
\text { budget tasks }\end{array}$ & 8.3 & 4.2 & 2.5 & 4.2 & 8.3 & 12.5 & 10.4 & 20.8 & 17.5 & 11.2 & 6.67 & 2.67 \\
\hline Save spaces & 6.2 & 5.4 & 2.5 & 5.0 & 9.2 & 11.7 & 13.8 & 19.2 & 15.4 & 11.7 & 6.65 & 2.59 \\
\hline Save money & 6.2 & 7.1 & 1.2 & 3.3 & 15.0 & 10.8 & 15.0 & 15.8 & 15.0 & 10.4 & 6.48 & 2.59 \\
\hline
\end{tabular}

Table 4. Overall Level of Attitude, Perceived Ease of Use, Self-efficacy and Subjective Norm

\begin{tabular}{lllll}
\hline Factors/ Level & Frequency & Percentage & Mean & S.D \\
\hline Perceived ease of use & & & $\mathbf{6 . 5 0}$ & $\mathbf{2 . 4 5}$ \\
Low (1-3.33) & 33 & 13.8 & & \\
Moderate (3.34-6.67) & 75 & 31.2 & \\
High (6.68-10.0) & 132 & 55.0 & $\mathbf{2 . 4 8}$ \\
Attitude & & & & \\
Low (1-3.33) & 45 & 18.8 & \\
Moderate (3.34-6.67) & 85 & 35.4 & \\
High (6.68-10.0) & 110 & 45.8 & $\mathbf{5 . 7 8}$ \\
Self-efficacy & & & & \\
Low (0-3.33) & 71 & 29.6 & \\
Moderate (3.34-6.67) & 78 & 32.5 & \\
High (6.68-10.0) & 91 & 37.9 & \\
Subjective norm & & & $\mathbf{5 . 3 2}$ \\
Low (0-3.33) & 51 & 21.2 & \\
Moderate (3.34-6.67) & 117 & 48.8 & \\
High (6.68-10.0) & 72 & 30.0 & \\
\hline
\end{tabular}


Table 5. Estimates of Coefficients for the Model

\begin{tabular}{lccccc}
\hline Factors & $\begin{array}{c}\text { B } \\
\text { (Unstandardized } \\
\text { Coefficients) }\end{array}$ & $\begin{array}{c}\text { Std. } \\
\text { Error }\end{array}$ & $\begin{array}{c}\text { Beta } \\
\text { (Standardized } \\
\text { Coefficients) }\end{array}$ & t & p-value \\
\hline \hline Constant & 1.809 & .318 & & 5.683 & .0001 \\
Attitude & .335 & .069 & .342 & 4.822 & .0001 \\
Self-efficacy & .163 & .065 & .187 & 2.504 & .013 \\
Perceived ease of use & .231 & .066 & .232 & 3.471 & .001 \\
Subjective norm & .134 & .062 & .117 & 2.157 & .032 \\
\hline
\end{tabular}

Notes: $\mathrm{R}=0.78 ; \mathrm{R}^{2}=0.60 ;$ Adj. $\mathrm{R}^{2}=0.60, \mathrm{~F}(6,240)=88.73$

Table 6. Correlation Table

\begin{tabular}{|c|c|c|c|c|c|c|}
\hline & & $\begin{array}{l}\text { Perceived usefulness } \\
\text { towards ICT usage }\end{array}$ & Attitude & Self-efficacy & $\begin{array}{l}\text { Perceived } \\
\text { ease of use }\end{array}$ & Subjective norm \\
\hline \multirow[t]{5}{*}{ Pearson Correlation } & $\begin{array}{l}\text { Perceived } \\
\text { usefulness } \\
\text { towards ICT } \\
\text { usage }\end{array}$ & 1.000 & .723 & .697 & .682 & .566 \\
\hline & Attitude & .717 & 1.000 & .777 & .708 & .614 \\
\hline & Sel-efficacy & .697 & .777 & 1.000 & .759 & .582 \\
\hline & $\begin{array}{l}\text { Perceived ease } \\
\text { of use }\end{array}$ & .682 & .708 & .759 & 1.000 & .565 \\
\hline & $\begin{array}{l}\text { Subjective } \\
\text { norm }\end{array}$ & .566 & .614 & .582 & .565 & 1.000 \\
\hline
\end{tabular}

